\title{
CORRESPONDENCE
}

\section{Progress in Crete}

SIR - The commentary on the current conditions in higher education and research in Greece by Mr E.M. Pantelouris, which appeared in your issue of 1/8 January, came to our attention with some delay. It is, however, instructive to examine the case of the University of Crete as an example of the roadblocks encountered in the actual implementation of innovative ideas and the measure of success that may be expected. This will also demonstrate, we hope, that some of the conclusions of Mr Pantelouris with regard to the University of Crete are not necessarily true.

The operations of the University of Crete started in the academic year 1977-78 with the Department of Mathematics of the School of Sciences at Heraklion and the School of Humanities at Rethymnon. The Department of Physics was added in 1978-79. During this formative phase, instruction was carried out by temporary staff hired on an annual basis and the university was housed in provisional quarters provided in high school buildings.

In spite of these shortcomings, the progress accomplished during the first three years of operation through the efforts of the Provisional Administrative Committee and the enthusiasm of the temporary staff has been remarkable. Some of the major

accomplishments include: (1) The organization of a library which already contains about 100,000 volumes in the humanities and 20,000 volumes in sciences. (2) The construction of provisional housing facilities for the schools of science and medicine which are expected to be ready for the academic year 1981-82. (3) The development of a flexible modern curriculum which has been already used successfully. And (4), the organization of student laboratories and the procurement of basic research equipment for the School of Sciences.

Clearly, however, the consolidation of these achievements and the future progress of the university depends critically, at this stage, on the recruitment of a high quality permanent faculty. The Administrative Committee has pushed from the beginning for a departmental structure, in contrast to the chair system, with a high professor to student ratio and a faculty with three professional ranks. The initial appointments will be made by faculty selection committees nominated by the Administrative Committee and consisting of professors from universities in Greece and abroad. These are new and unprecedented features for the Greek university system and it is not surprising that the legislation required for their implementation was time consurning.

This work is now complete and a call for candidacies for 24 positions in the School of Sciences and 14 positions in the School of Humanities has been publicized (see Nature classified columns of 29 January). The faculty selection committees have been nominated and the first appointments are expected to be made by late autumn this year. These, of course, are only the first steps in consolidating the structure of the new university and much persistent and enlightened effort will be required especially by the first members of the faculty. The course of the campaign for reforms in the system of higher education in Greece has demonstrated so far that while a diagnosis of flaws and deficiencies is common knowledge, the planning and implementation of effective steps for lasting changes is an agonizing procedure, replete with frustrations but highly rewarding when successful. We hope that the University of Crete will play a significant role in this by setting an example of a high quality modern institution of higher education and research.

A. Kostikas

(Member of Administrative Committee) Crete University, Greece

\section{Xeroderma list}

SIR - The issues raised in Cairns's article "The origin of human cancers"' 1 and subsequent comments ${ }^{2}$ highlight the importance of studies of rare human disorders as models for human carcinogenesis. In order to gain quantitative information on such questions as the frequency of cutaneous and internal neoplasms in patients with defective DNA repair, we are establishing a registry of xeroderma pigmentosum patients. We welcome correspondence from physicians and scientists who are aware of American patients with xeroderma pigmentosum:

Xeroderma Pigmentosum National Registry, c/o Department of Pathology,

Medical Science Building, Room C520,

CMDNJ-New Jersey Medical School, 100 Bergen Street,

Newark, New Jersey 07103, USA

Alan D. ANDrews

JAMES L. GERMAN III W. Clark-LAMBert

Columbia University, The New York

Blood Center, NIH

and $C M D N J-T h e$ New Jersey

Medical Center, USA

1. Cairns, J. Nature 289, 353-357 (1981)

2. Trosko, J. Nature 290, $356(1981)$.

\section{Be nice to NATO}

SIR - Mr Roger R.C. New has recently argued in these columns against publicizing the NATO Advanced Study Institutes in Nature on the grounds that it implies approval for "the increasing military orientation of our society"' (Nature 23 April, p.624). I take precisely the opposite point of view (neither of us questions the scientific and pedagogical value of these institutes).

Surely lasting peace can only be established on this planet if a framework of trans-national judicial, political and economic institutions can be developed to cope with the problems plaguing all mankind. In my view the construction of such institutions must begin with those nations sharing a common democratic tradition - basically those encompassed by NATO and/or OECD. NATO has always been intended as more than a military alliance; I note Article 9 of the Treaty, establishing the "North Atlantic Council" for political consultation, and the meetings of the NATO parliamentarians.

Expansion and encouragement of multinational intellectual, economic and ultimately political ties among the citizens of the world's democracies must be urgently pursued, and the NATO Advanced Study Institutes play a small but positive role in such developments.

William M. IRVINE

Chalmers University of Technology,

Onsala Space Observatory, Sweden

\section{Computer algebra}

SIR - I was delighted to see your recent article on "Algebra made mechanical" (Nature 19 March p.198). These symbolic math systems will surely revolutionize scientific computation. However, there is one minor correction to the article: muMATH was coauthored by Albert D. Rich and myself at The Soft Warehouse. Also, to redirect the deluge of enquiries, I suggest that they be sent directly to the distributor: Microsoft Consumer Products at 400 108th Ave. N.E., Suite 200, Bellevue, Washington 98004, USA.

The Soft Warehouse,

DAvid R. StOUTEMYeR Hawaii, USA

\section{Confusing script}

SIR - In the debate stimulated by Halstead's 1 criticisms of the Natural History Museum's exhibit on human evolution, there are two main issues which only partly overlap. First, what cladism entails, and what various authors think about it; and second whether the museum's exhibit presents a fair picture of human evolution, as it is known to science.

Those who disagree with Halstead about the former would do well not to prejudge his assessment of the latter, without seeing the exhibit. B.A. Wood's ${ }^{2}$ observations that some early hominids have been seriously misassigned should be noted. So far the archaeological side to the exhibit has passed without comment, but one particular example, in which archaeology and physical anthropology are brought together, speaks volumes for the general tone of the exhibit.

First, it is suggested, reasonably enough, that neanderthals have characteristics not shared by modern man, and vice versa. Then the script continues

"But because the neanderthals and modern man share these two important characteristics

- an average brain size of $1,330 \mathrm{ml}$

- burial of the dead they can be grouped together in the same species - Homo sapiens". This confused conjunction of biometrical and cultural criteria is so weird that little more need be said. But other oddities abound. We are told that we are apes, without any reference to the pattern of characteristics which distinguish us as hominids. Then, the whole, vital, subject of chronology is almost totally omitted.

It seems unlikely that the exhibit represents "official" doctrine of the museum concerning cladism. It represents a good visual show, in which unfortunately “educationalese"' has taken over to the extent that the children and other visitors who much enjoy the exhibit are seriously and unnecessarily misled by gross oversimplifications. This is a great pity, for in many ways meticulous care has been taken in the preparation of the exhibit. The desire to simplify in order to spread knowledge is understandable, but over-simplification at the expense of accuracy is counterproductive, and does little to further learning.

JOHN A.J. GOWLETT

Research Laboratory for Archaeology

and the History of Art,

Oxford, UK

1. Halstead, L.B. Nature 288, 208 (1980)

2. Wood, B.A. Nature 289, 8 (1981) 